\title{
Comparison of Different Antinucleic Acid Antibody Spectrotypes in Spontaneous, Induced, and Murine Lupus
}

\author{
Michael Fischbach, Judith Rabbie, and Norman Talal, Section of \\ Immunology/Arthritis, Veterans Administration Medical Center, and \\ Department of Medicine, University of California, \\ San Francisco, California 94121
}

\begin{abstract}
A B S T R A C T Sera from patients with systemic lupus erythematosus and from mice spontaneously developing lupus were subjected to isoelectric focusing by a microsucrose gradient method. The spectrotypes of human antibodies to native DNA, denatured DNA, and polyriboadenylic acid (poly A) were compared. Antibodies to native DNA and denatured DNA focused into two regions whose boundaries were pH 5.0-7.0 and $\mathrm{pH}$ 8.5-10.0. Antinative DNA antibodies were more homogeneous than antidenatured DNA antibodies. Anti-DNA antibodies in cryoglobulins showed more restriction than those present in serum. There was no relationship between spectrotype and pattern of disease expression. Murine antibodies to native DNA were more heterogeneous than human anti-DNA antibodies. The spectrotypes of antidenatured DNA antibodies from patients with systemic lupus erythematosus or drug induced lupus, or from an immunized rabbit, were similar. Likewise, antibodies to poly A were similar in both human and murine lupus. In contrast to anti-DNA, antibodies to poly A were restricted and focused only in the alkaline range $(\mathrm{pH}$ 9.5-10.0). The spectrotype of antipoly $\mathrm{A}$ antibodies induced by lipopolysaccharide were comparable but had an additional small band at pH 6.2

Our results suggest unique antibody spectrotypes with varying degrees of restriction for different nucleic acid antigens. Furthermore, spontaneous and induced autoantibodies have similar spectrotypes. Thus, the B cell clones producing antinucleic acid antibodies may be similar whether they are activated spontaneously, following immunization, or as a consequence of polyclonal stimulation.
\end{abstract}

Received for publication 2 March 1981 and in revised form 1 June 1981.

Dr. Fischbach's current address is Department of Medicine, University of Texas Health Science Center, San Antonio, Tex.

\section{INTRODUCTION}

Antibodies to nucleic acids are important features of autoimmunity $(1,2)$, and are of pathogenic significance in systemic lupus erythematosus (SLE) ${ }^{1}(3)$. The qualitative characteristics of the antibody molecules, particularly antibodies to native DNA, may be important determinants of clinical subset or severity. Various functional properties, e.g., antigen affinity, are very likely related to different structural configurations of the antibody molecule.

According to the clonal selection hypothesis, antibody heterogeneity reflects $B$ lymphocyte heterogeneity (4). Therefore, the study of autoantibody heterogeneity can be a clue to the degree of lymphocyte dysregulation that permits their production. The size of the spontaneous antinucleic acid antibody repertoire can be estimated from the spectrotype determined by analytical isoelectric focusing.

We have adapted the microsucrose density gradient isoelectric focusing method of Press and Klinman (5). This method eliminates the need for purification of antinucleic acid antibodies before focusing or for radioautography after focusing. Both IgG and IgM antibodies can be analyzed after focusing by standard radioimmunoassay procedures for antinucleic acid antibodies.

In this study we have investigated the heterogeneity of human and murine lupus antibodies directed against native and denatured DNA, and against polyriboadenylic acid (poly A). The antibody spectrotype is compared with antibodies from patients with druginduced lupus, and from immune rabbit serum. Lupus patients representing different clinical subsets were analyzed, as were anti-DNA antibodies present in

${ }^{1}$ Abbreviations used in this paper: poly A, polyriboadenylic acid; SLE, systemic lupus erythematosus. 
murine cryoglobulins. These studies suggest unique antibody spectrotypes with varying degrees of restriction for different nucleic acid antigens.

\section{METHODS}

Patients. 10 patients (9 females and 1 male) who fulfilled the American Rheumatism Association criteria for SLE (6) and were not treated with corticosteroids or immunosuppressives were studied.

Four additional study patients (three male and one female) receiving either procainamide or hydralazine were diagnosed as having drug-induced lupus based on the abrupt onset of symmetrical polyarthralgias, myalgias, fever, or pleuritis with sterile pleural effusions. There was no evidence of renal or central nervous system involvement. All patients had positive antinuclear antibody immunofluorescence, and elevated antidenatured DNA antibody titers, but no antinative DNA or antipoly A antibodies. Serum complement concentrations were normal. All signs and symptoms disappeared after cessation of procainamide or hydralazine therapy. Sera were stored at $-20^{\circ} \mathrm{C}$ before use.

Mice. BALB/c mice were purchased from The Jackson Laboratory (Bar Harbor, Maine). MRL/lpr and NZB/NZW $F_{1}$ mice were obtained from our colony at the Animal Care Facility, University of California, San Francisco. Mice were bled by orbital sinus puncture, and sera stored at $-20^{\circ} \mathrm{C}$.

Rabbits. New Zealand White rabbits were immunized with heat-denatured DNA-methylated bovine serum albumin, prepared by heating calf thymus DNA (Worthington Biochemical Corp., Freehold, N. J.). to $100^{\circ} \mathrm{C}$ for $10 \mathrm{~min}$, followed by immediate cooling to $4^{\circ} \mathrm{C}$. An equal weight of methylated bovine serum albumin (Sigma Chemical Co., St. Louis, Mo.) was added with constant stirring (7). Rabbits were given three weekly injections of $1 \mathrm{mg}$ DNA at multiple sites and bled 1 wk later. This immune rabbit serum had antibody activity for denatured but not native DNA.

Mitogens. LPS from Salmonella typhimurium (Difco Laboratories, Detroit, Mich.) was injected intraperitonally into BALB/c mice at a dose of $100 \mu \mathrm{g}$ as described (8). Sera were tested and stored at $-20^{\circ}$ until used as a source of experimentally induced antipoly $A$ antibodies.

Isoelectric focusing. Isoelectric focusing was performed according to the method of Press (5). Cylindrical glass tubes $115 \mathrm{~mm} \times 5 \mathrm{~mm}$ were covered at one end with dialysis tubing. The tubes were filled by successively layering $250 \mu \mathrm{l}$ of 50 , 40 , and $30 \%$ sucrose; $150 \mu \mathrm{l}$ of diluted serum mixed with 150 $\mu \mathrm{l}$ of $50 \%$ sucrose was layered on top of the $30 \%$ sucrose layer. The remaining portion of the tubes were filled with $250 \mu \mathrm{l}$ of $20 \%$ sucrose. The tubes were placed in an isoelectric focusing apparatus (Hoefer Scientific Instruments, San Francisco, Calif.). The anode buffer was phosphoric acid diluted to $1.5 \%$ with $50 \%$ sucrose. The cathode buffer was $10 \%$ ethanolamine. The tubes were focused for $16 \mathrm{~h}$ at $160 \mathrm{~V}$ at $4^{\circ} \mathrm{C}$. After focusing, the tubes were placed on a plastic support that contained a silicone center. A 22-gauge needle was inserted through the silicone into the dialysis membrane. Single drops were collected, and each drop was assayed for antibody activity. The $\mathrm{pH}$ was determined by collecting each drop in $0.5 \mathrm{ml}$ of $0.15 \mathrm{M}$ saline for immediate reading in a Beckman pH meter (Beckman Instruments, Inc., Fullerton, Calif.). The slope of the $\mathrm{pH}$ gradient was relatively flat from $\mathrm{pH} 9.0-10.0$. This gave broad focusing bands in the region.

Isoelectric focusing in polyacrylamide. The mouse myeloma UPC 10 was focused according to the method of Tung (9) in cylindrical $5 \times 115 \mathrm{~mm}, 5 \%$ polyacrylamide gels; acrylamide, $4.85 \%$; bisacrylamide, $0.15 \%$ riboflavin, $5 \times 10^{-3} \% ; N, N, N^{\prime}, N^{\prime}$-tetramethylethylenediamine, $0.05 \%$; urea, 3.5 M; all obtained from Bio-Rad Laboratories (Richmond, Calif.); Ampholine, $2 \% \mathrm{pH} 3.5-10.5$, obtained from LKB Instruments, Inc. (Rockville, Md.). $50 \mu \mathrm{g}$ of protein in 20 $\mu \mathrm{l}$ of $2 \%$ Ampholine ampholyte solution was placed on top of the polyacrylamide. The cathode contained $2 \%(\mathrm{vol} / \mathrm{vol})$ ethanolamine and the anode $1.5 \%$ phosphoric acid. Focusing was carried out in the cold room starting with a constant current of $1 \mathrm{~mA} /$ tube; when the voltage reached $450 \mathrm{~V}$, it was maintained at this level for $6-8 \mathrm{~h}$.

Gels were stained by Coomasie Blue dye. The $\mathrm{pH}$ was determined by slicing the gel into 5 -mm portions. Each portion was added to $0.5 \mathrm{ml}$ degassed saline, allowed to settle, and the $\mathrm{pH}$ measured.

Anti-DNA and antipoly A antibody assays. Antibodies to DNA and poly $A$ were measured by the cellulose ester filter radioimmunoassay method described $(10)$. $\left[{ }^{3} \mathrm{H}\right] \mathrm{DNA}$ from Escherichia coli (New England Nuclear, Boston, Mass., sp act, $1.8 \mu \mathrm{g} / \mu \mathrm{Ci}$ ) was used at a concentration of $3 \mathrm{ng} / 10 \mu \mathrm{l}$ (representing $\sim 1,000 \mathrm{cpm}$ ). To assure a maximum degree of doublestrandedness, the DNA was treated with $S_{1}$ nuclease (Calbiochem-Behring Corp., San Diego, Calif.) according to the method of Locker et al. (11). The reaction mixture was passed over a benzoylated naphtholyated DEAE cellulose column (Sigma,Chemical Co.). Double-stranded DNA was removed with $1 \mathrm{M}$ saline, dialyzed into borate-buffered saline $(0.15 \mathrm{M}, \mathrm{pH} 8)$, and concentrated to the value given above. ${ }^{3} \mathrm{H}$-DNA was heat denatured by boiling for $10 \mathrm{~min}$, followed by rapid cooling to $4^{\circ} \mathrm{C}$. $\left[{ }^{3} \mathrm{H}\right]$ polyriboadenylic acid (Miles Laboratories, Inc., Elkhart, Ind., $\mathrm{S}_{20} 6.2$, sp act 5.9 $\mu \mathrm{g} / \mu \mathrm{Ci}$ ) was used at a concentration of $11.3 \mathrm{ng} / 10 \mu \mathrm{l}$, (representing $\sim 1,000 \mathrm{cpm}$ ).

Each drop of isoelectric focusing fraction, $\sim 10 \mu \mathrm{l}$, was brought to $90 \mu \mathrm{l}$ in borate-buffered saline $(0.15 \mathrm{M} \mathrm{pH} 8)$ and decomplemented by heating at $56^{\circ} \mathrm{C}$ for $30 \mathrm{~min}$. $10 \mu \mathrm{l}$ of tritiated nucleic acid was added, followed by incubating at $37^{\circ} \mathrm{C}$ for $30 \mathrm{~min}$, and at $4^{\circ} \mathrm{C}$ overnight. The immune complexes were then collected on $0.45-\mu \mathrm{m}$ cellulose ester filters (Millipore Corp., Bedford, Mass.). The filters were dried, placed in counting vials, and covered with $10 \mathrm{ml}$ LiquifluorToluene scintillation fluid. Radioactivity was determined in a Packard liquid scintillation counter (Packard Instrument Co., Inc., Downers Grove, Ill.). The radioactivity retained on the filter is directly related to the serum antibody concentration (12). Sucrose did not interfere with antibody binding.

Inhibition study. The specificity of binding was determined by blocking with various unlabeled nucleotides. Poly dA, poly dT, poly dG, poly dC, and poly rA were obtained from Miles Laboratories. Calf thymus DNA was obtained from Worthington Laboratories. 10-fold serial dilutions of unlabeled polynucleotide or nucleic acid (from 0.01 $\mu \mathrm{g}$ to $10 \mu \mathrm{g}$ ) were incubated with either serum or individual fractions (Results) at $37^{\circ} \mathrm{C}$ for $30 \mathrm{~min}$. The serum, or individual fractions, were either focused or assayed in the usual manner.

Affinity chromatography. Sepharose 4B (Pharmacia Fine Chemicals, Uppsula, Sweden) was activated with cyanogen bromide in acetronitrile according to the method of March et al. (13) and coupled to polyvalent goat antihuman immunoglobulin (Meloy Laboratories Inc., Springfield, Va.). $10 \mathrm{~g}$ of activated Sepharose 4B were reacted with $50 \mathrm{mg}$ of goat antihuman immunoglobulin in $0.1 \mathrm{M} \mathrm{NaHCO}_{3}, 0.15 \mathrm{M} \mathrm{NaCl}, \mathrm{pH}$ 8 . The reaction was continued for $18 \mathrm{~h}$ at $4^{\circ} \mathrm{C}$. Unreactive sites were blocked by adding $1 \mathrm{M}$ ethanolamine for $2 \mathrm{~h}$ at room temperature.

Affinity chromatography was performed by passing of $1 \mathrm{ml}$ of serum over $5 \mathrm{ml}$ of Sepharose-congugated antihuman immunoglobulin. The nonadherent serum proteins were collected. The column was washed with phosphate-buffered saline. Absorbed proteins were eluted with glycine- $\mathrm{HCl} \mathrm{pH}$ 
2.3, and dialyzed into borate-buffered saline. Eluted material was concentrated to the immunoglobulin concentration of whole serum. By immunoelectrophoresis and Ouchterlony analysis, the eluted proteins were found to contain only immunoglobulins. Protein concentrations were determined by optical density measurement of $280 \mathrm{nM}$ in a Gilford spectrophotometer (Gilford Instrument Laboratories, Inc., Oberlin, Ohio).

Cryoglobulins. MRL/lpr mouse serum was allowed to clot at $37^{\circ} \mathrm{C}$. The clot was removed and serum placed at $4^{\circ} \mathrm{C}$ for $72 \mathrm{~h}$. The cryoglobulins were collected and extensively washed in borate-buffered saline. The cryoglobulins were placed in solution by warming to $37^{\circ} \mathrm{C}$, and antibody activity determined by the usual method. The cryoglobulins were diluted to $40 \%$ antigen binding and focused in the usual manner.

\section{RESULTS}

To determine the discriminatory ability of our system, two mouse myelomas were focused: UPC 10 (IgG2a, $\kappa)$ and MOPC $104 \mathrm{E}(\operatorname{IgM}, \lambda)$. Each fraction was assayed by immunoprecipitation in gel with monospecific antisera. The IgG2a myeloma focused over a pH range 6.98 to 7.34 ( $0.36 \mathrm{pH}$ units), the IgM myeloma over a $\mathrm{pH}$ range of 6.17 to 6.57 ( $0.4 \mathrm{pH}$ units). The microsucrose gradient technique was then compared with standard isoelectric focusing in $5 \%$ polyacrylamide gel tubes. UPC 10 was again focused. Five bands identified by Coomasie Blue staining, spanning a $\mathrm{pH}$ range from 7.0 to $7.3(0.3 \mathrm{pH}$ units) suggested that the two techniques yielded fairly comparable resolution. A $\kappa$-type monoclonal IgG2a obtained from a MRL/pr murine hybridoma with antibody activity against both native and denatured DNA was studied by the sucrose gradient technique as a monoclonal standard for radioimmunoassay. It focused with six discrete peaks from pH 9.4 to 9.9 (0.5 pH units, Fig. 1). The slope of the $\mathrm{pH}$ gradient in the alkaline region is relatively flat com-

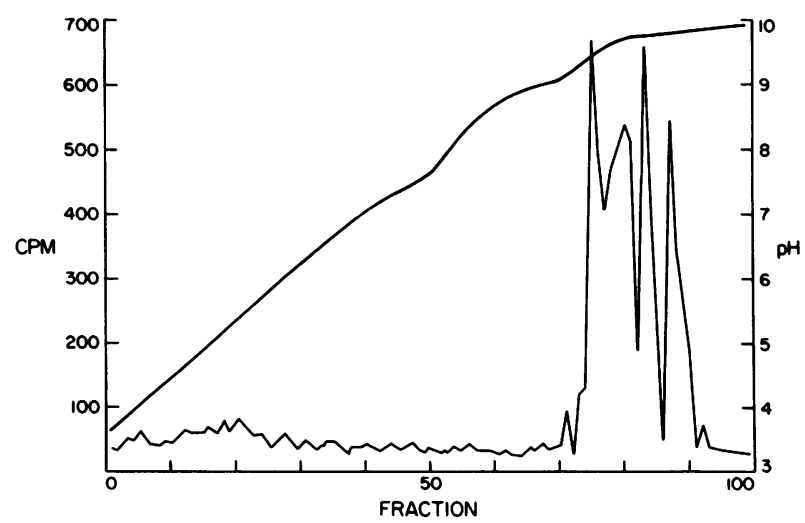

FIGURE 1 Isoelectric focusing spectrotype of a monoclonal IgG2a kappa antinative DNA antibody from a MRL/lpr hybridoma. Each 10- $\mu$ l fraction was assayed for binding to $\left[{ }^{3} \mathrm{H}\right] \mathrm{DNA}$ and expressed as counts per minute. The diagonal darker line represents a $\mathrm{pH}$ gradient. pared with the rest of the $\mathrm{pH}$ gradient. As a result, the antibody peaks are broad.

The isoelectric focusing spectrotype of antinucleic acid antibodies in SLE. There was no binding of native DNA, dentured DNA, or poly $A$ in the focused fractions of sera from normal individuals lacking antinucleic acid antibodies.

Preliminary experiments using sera from patients with SLE demonstrated wide variations in both serum immunoglobulin concentrations and nucleic acid binding. To compare isoelectric focusing profiles from different individuals, whole serum was routinely diluted to a level of $50 \%$ antigen binding. This permitted good resolution of discrete proteins and was used throughout the study.

Focusing was performed on sera from 10 patients with SLE whose disease was assessed as clinically active by high titered anti-DNA antibodies, decreased total hemolytic complement, and either active renal disease, pericarditis, or pleuritis. Figs. 2, 3, and 4 are the focusing patterns from three representative patients with biopsy evidence of severe renal involvement. They all had biopsy evidence of diffuse proliferative glomerulonephritis. Serum creatinines ranged from 1.9 to $2.5 \mathrm{mg} / 100 \mathrm{ml}$. Patients with focal or mesangial glomerulonephritis or any evidence of necrosis were excluded. Each patient had a unique pattern. Antibodies to native DNA (Figs. 2a, 3a, and 4a) were more homogeneous than antibodies to denatured DNA (Figs. 2b, 3b, and 4b). Antibodies to denatured DNA focused in two major regions ( $\mathrm{pH}$ 5.0-7.0 and 8.5-10.0). Antinative DNA antibodies always contained the acidic bands, whereas the alkaline bands were variably present.

There was no spectrotype of free anti-DNA antibodies that was characteristic of patients with or without diffuse glomerulonephritis. Similar acidic and alkaline banding patterns were found in patients with no clinical evidence of renal disease and those with severe glomerulonephritis.

Antibodies to poly A focused only in the alkaline region $\mathrm{pH}$ 9.5-10.0 in all 10 patients regardless of clinical state.

To assess the specificity of binding, sera were absorbed with unlabeled DNA or poly A before focusing. A 1,000-fold excess of poly A completely abolished the poly $\mathrm{A}$ focusing pattern, but did not influence the spectrotype seen with DNA. Likewise, absorption with DNA in a concentration 1,000 times that used in the radioimmunoassay abolished both native and denatured DNA binding patterns but did not affect the spectrotype seen with poly $\mathrm{A}$. To assure that the nucleic acid binding was due to immunoglobulin, sera were passed over an antiimmunoglobulin affinity column. The nonadherent proteins were concentrated to the same value as serum proteins and subjected to iso- 

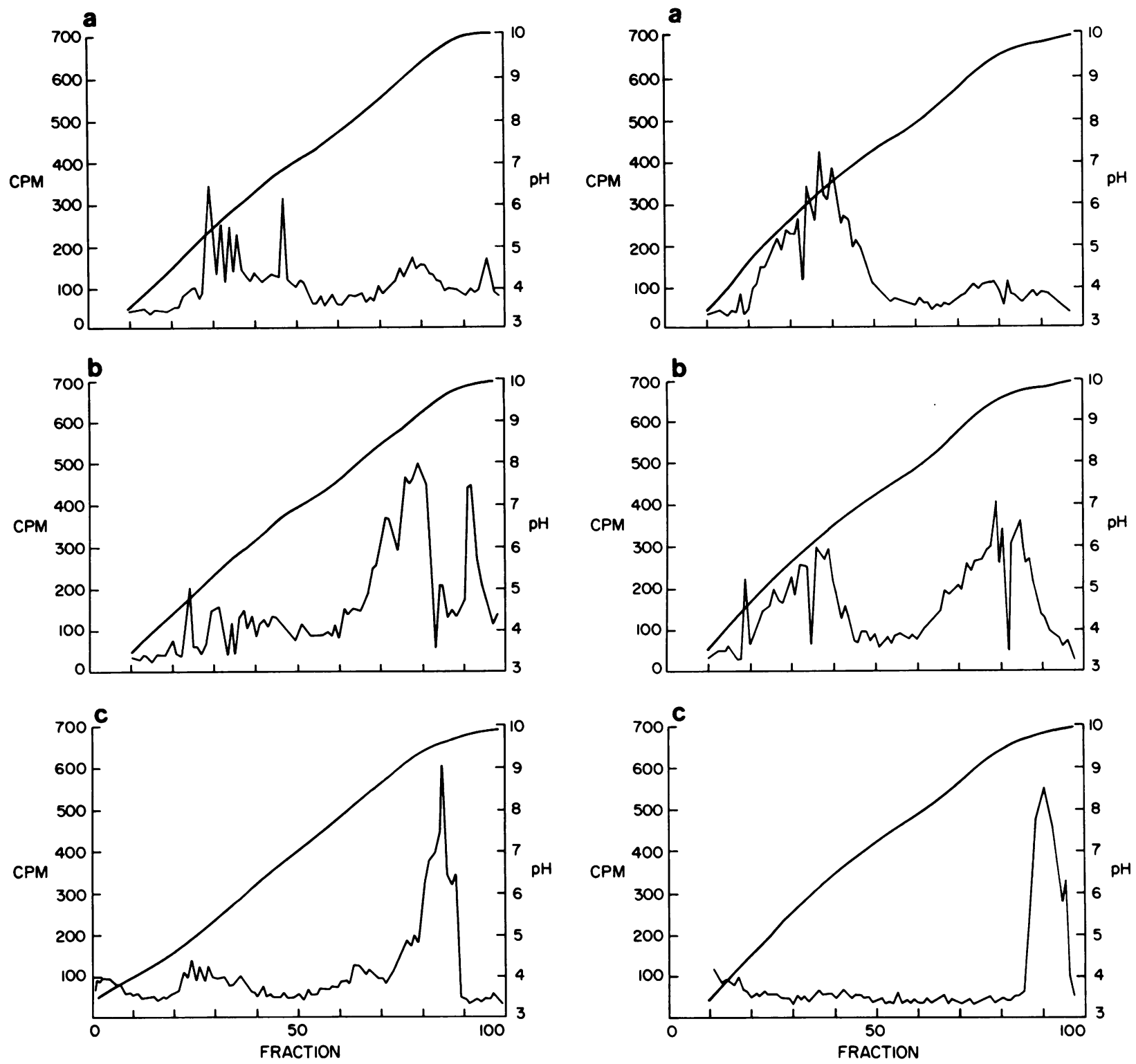

Figure 2 Comparison of isoelectric focusing spectrotype of different antinucleic acid antibodies from the serum of an SLE patient. (a) The spectrotype of antinative DNA antibodies. (b) The spectrotype of antidenatured DNA antibodies. (c) The spectrotype of antipoly rA antibodies. The serum was diluted to $50 \%$ antigen binding for each antigen before focusing.

electric focusing. No antinucleic acid binding was observed. The binding material eluted from the affinity column focused in the usual manner. To assure that IgG was present in the alkaline $\mathrm{pH}$ region, the focused fractions were analyzed by Ouchterlony analysis with monospecific goat antihuman IgG. IgG was present in the alkaline fractions $\mathrm{pH}$ 9.0-10.0.

The isoelectric focusing spectrotypes of different

FIGURE 3 Comparison of isoelectric focusing spectrotype of different antinucleic acid antibodies from the serum of an SLE patient. (a) The spectrotype of antinative DNA antibodies. (b) The spectrotype of antidenatured DNA antibodies. (c) The spectrotype of antipoly $\mathrm{rA}$ antibodies. The serum was diluted to $50 \%$ antigen binding for each antigen before focusing.

antidenatured DNA antibodies. Antidenatured DNA antibodies from four patients with drug-induced lupus were individually focused. A representative pattern is shown in Fig. 5. The spectrotype is similar to that obtained from patients with spontaneous SLE (Figs. $2 \mathrm{~b}, 3 \mathrm{~b}$, and $4 \mathrm{~b})$. This spectrotype is contrasted with the spectrotypes of serum obtained from a rabbit immunized with denatured DNA methylated serum 

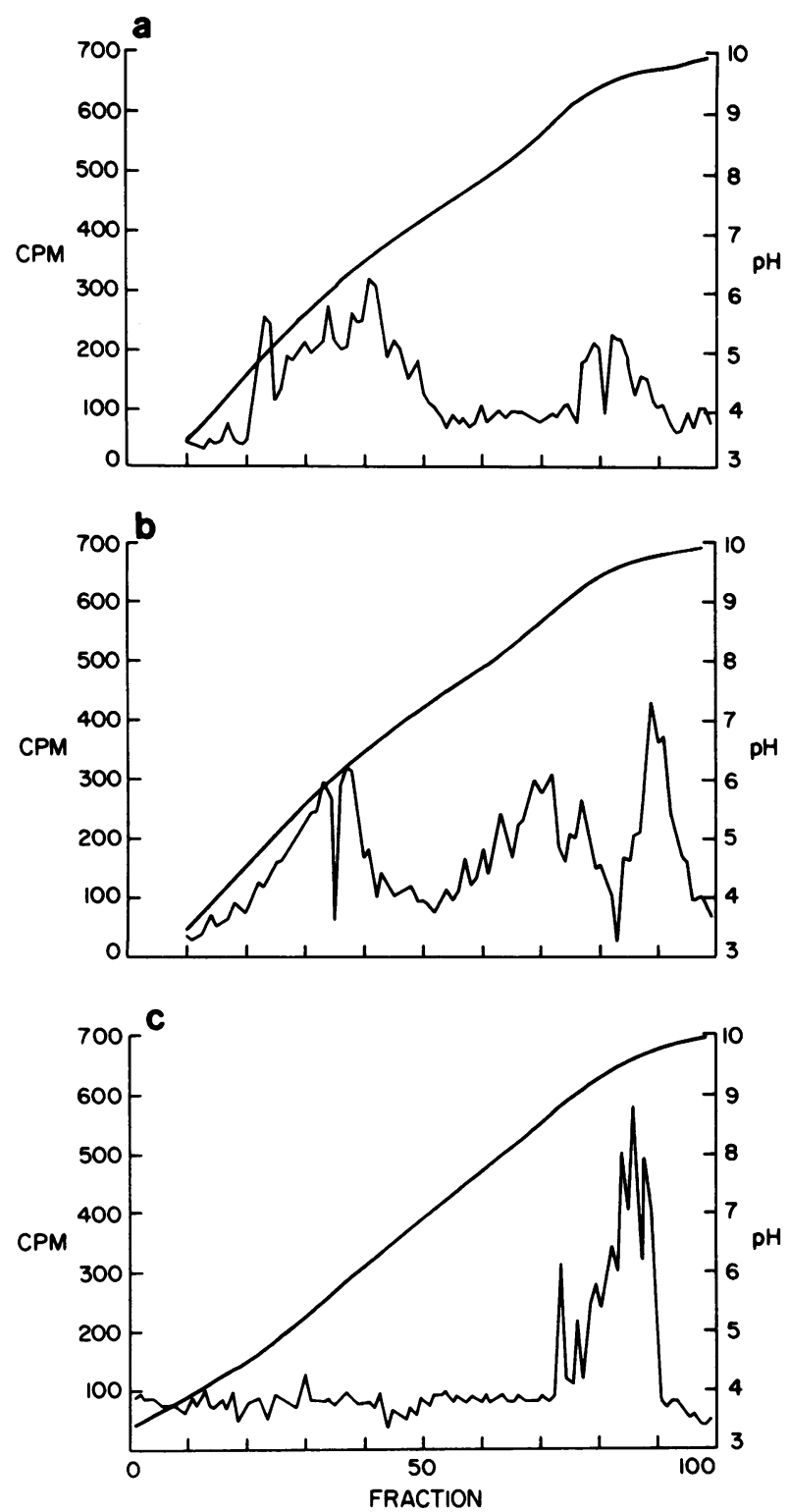

FIgURE 4 Comparison of isoelectric focusing spectrotype of different antinucleic acid antibodies from the serum of an SLE patient. (a) The spectrotype of antinative DNA antibodies. (b) The spectrotype of antidenatured DNA antibodies. (c) The spectrotype of antipoly $\mathrm{rA}$ antibodies. The serum was diluted to $50 \%$ antigen binding for each antigen before focusing.

albumin (Fig. 6). This spectrotype is somewhat similar with most of the antibody bands present in the alkaline region, but the immunized rabbit serum contained additional bands at $\mathrm{pH} 4.0-4.5$.

The polynucleotide inhibition of antidenatured DNA antibodies. To determine if antibodies with a particular isoelectric point were associated with a

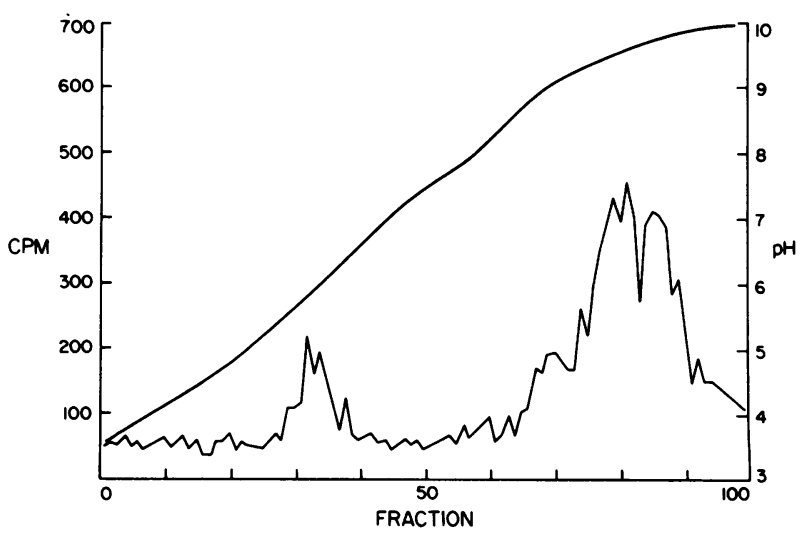

FIGURE 5 Isoelectric focusing spectrotype of antidenatured DNA antibodies from the serum of a patient with hydralazineinduced lupus.

specific nucleotide specificity, sera from SLE patients were studied by two experimental approaches: $(a)$ serum was absorbed with either poly $\mathrm{dT}$, poly dC, poly $\mathrm{dG}$, or poly $\mathrm{dA}$ before focusing, and then studied in the usual manner; $(b)$ serum was focused as usual, and then the individual fractions were absorbed with the polynucleotides. The polynucleotides were used at concentrations that gave $60 \%$ inhibition of antidenatured DNA antibodies in whole serum.

Neither type of inhibition eliminated antibodies from any particular $\mathrm{pH}$ regions. The magnitude of the antibody bands were decreased and the spectrotypes were somewhat changed, but there was no evidence that particular antibody bands were associated with particular polynucleotide specificities.

The isoelectric focusing spectrotype of antinucleic acid antibodies in murine lupus. The spectrotype of antibodies from autoimmune mice were compared

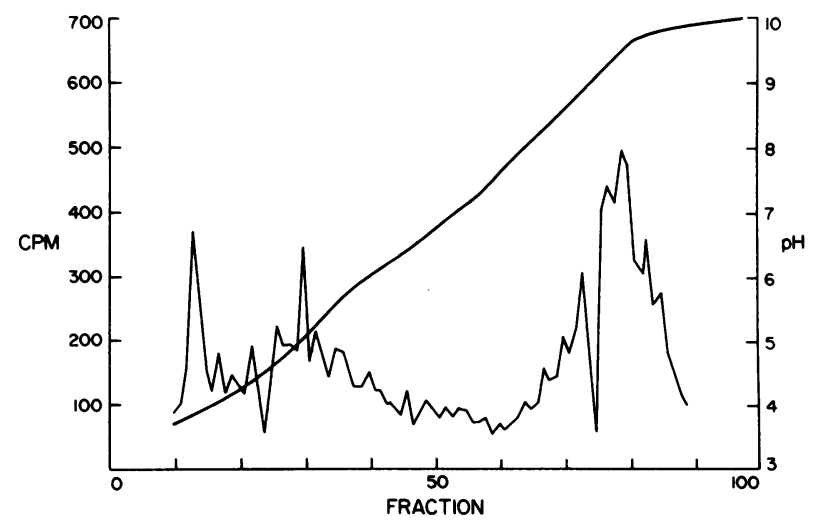

FIGURE 6 Isoelectric focusing spectrotype of antidenatured DNA antibodies from the serum of a rabbit immunized with DNA-methylated bovine serum albumin. 

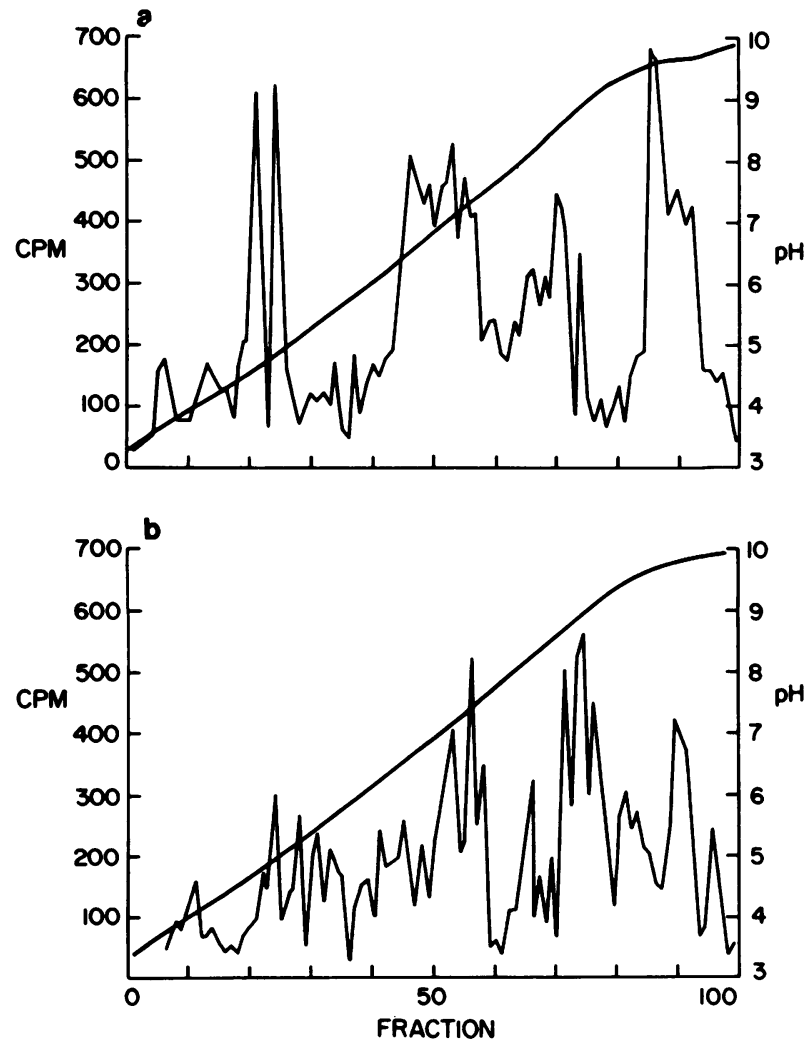

FIGURE 7 Isoelectric focusing spectrotype of murine antinative DNA antibodies: (a) The spectrotype of serum from a 5-mo-old MRL/lpr mouse. (b) The spectrotype of serum from an 8-mo-old NZB/NZW $F_{1}$ mouse.

with that observed in lupus patients. Antinative DNA antibodies from four 5-mo-old MRL/pr and four 8-moold NZB/NZW $F_{1}$ mice were similar (Fig. 7). The spectrotypes were more heterogeneous than those of human anti-DNA antibodies. In contrast, the spectrotype of antipoly A antibodies (Fig. 8a) were similar to the human and localized to the alkaline region.

The isoelectric focusing spectrotype of experimentally induced antibodies to poly A. Lipopolysaccharide (LPS) was injected into five BALB/C mice as polyclonal activator to induce antipoly $A$ antibodies (8). The spectrotype of these experimentally induced antibodies was similar to that of spontaneous human and murine antipoly $A$ antibodies. There was an additional peak at $\mathrm{pH} 6.5$, but the majority of antibody focused in the alkaline region (Fig. 8b).

The isoelectric focusing spectrotype of antinucleic acid antibodies concentrated in cryoglobulins. Sera and isolated cryoglobulins from five MRL/lpr mice were simultaneously focused (Fig. 9). In all cases, the spectrotype of anti-DNA antibodies in the cryoglobulins showed more restriction than the spectrotype from whole serum. The alkaline antibody bands were absent from the cryoglobulins.

\section{DISCUSSION}

This study demonstrates selective heterogeneity of antibodies reactive with different nucleic acid antigens. Antibodies to native DNA were more restricted than antibodies to denatured DNA. The greater heterogeneity seen with antidenatured DNA antibodies is not surprising, since these antibodies are found in many disease states $(14,15)$. Antinative DNA antibodies are almost exclusively limited to SLE (11). The most restricted heterogeneity was seen with antipoly $A$ antibodies. There are probably fewer antigenic sites on the homopolymer, poly A, than on DNA, possibly explaining the more restricted focusing pattern.

The highly alkaline isoelectric point ( $\mathrm{I} I)$ of these antibodies is unusual but not unique. Such exceptionally basic IgG have been found in the cerebrospinal fluid of patients with multiple sclerosis $(16,17)$
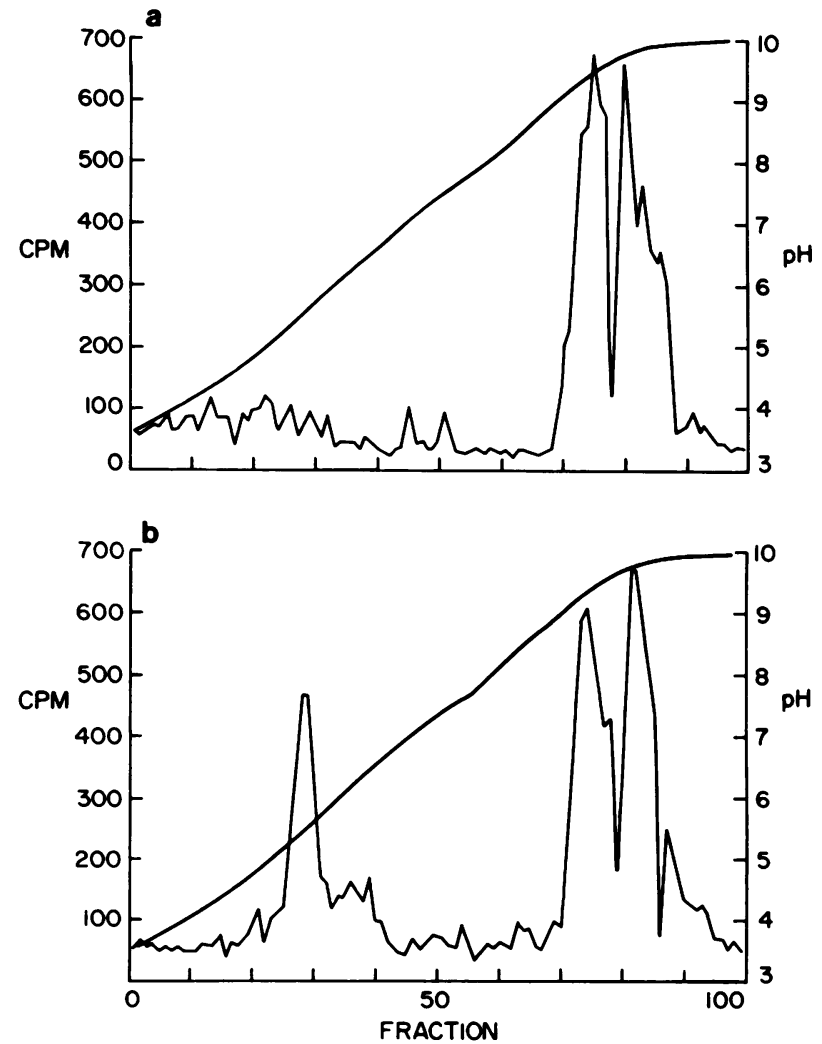

FIGURE 8 Comparison of isoelectric focusing spectrotypes of spontaneous and induced murine antipoly rA antibodies: (a) The spectrotype of spontaneous antipoly $\mathrm{rA}$ antibodies from the serum of a 5-mo-old MRL/lpr mouse. (b) The spectrotype of induced antipoly rA antibodies from the serum of a BALB/c mouse stimulated with lipopolysaccharide. 

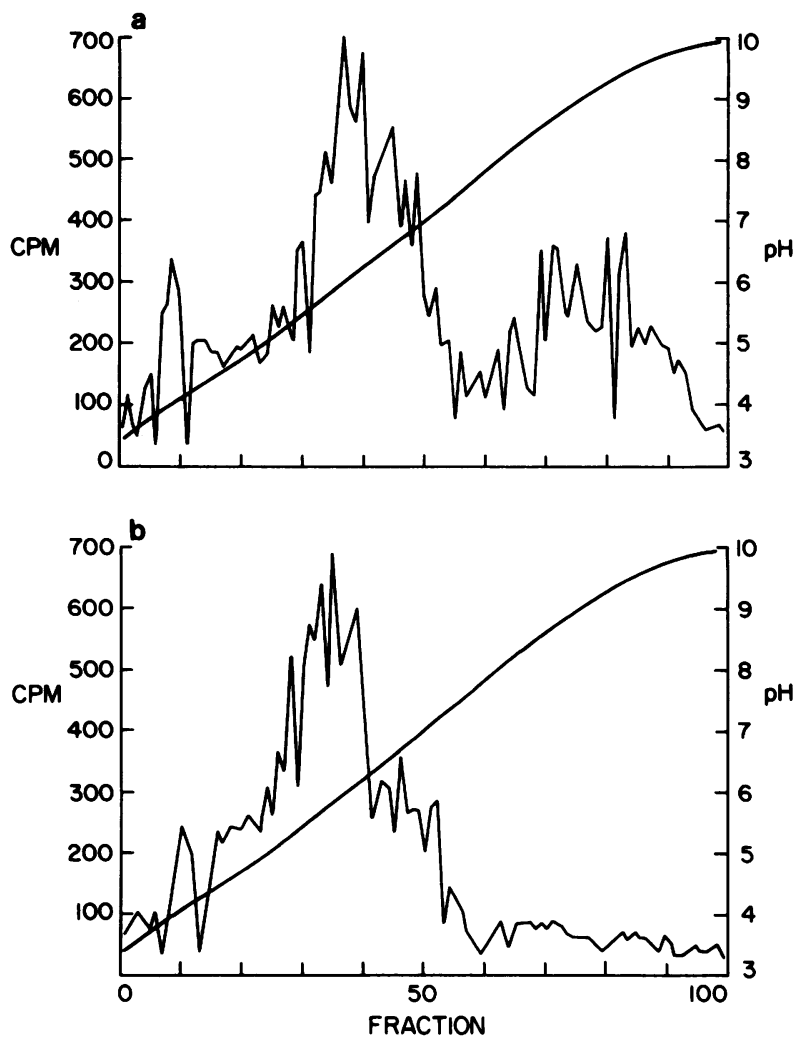

FIGURE 9 Comparison of isoelectric focusing spectrotypes of MRL/lpr antinative DNA antibodies from serum and isolated cryoglobulins: (a) The spectrotype of serum. (b) The spectrotype of isolated cryoglobulin.

and in the serum of patients with papular mucinosis (18, 19). Whether the pI is due to IgG alone is unknown. We are currently investigating the possibility that IgG may be complexed with another substance, perhaps antigen.

This study also demonstrates that the microsucrose gradient isoelectric focusing technique is applicable to the study of antinucleic acid antibodies. This technique offers the advantage of assaying focused antibody under radioimmunoassay conditions, and minimizing the interference caused by nonspecific binding components in normal serum. Although major bands can be distinguished easily and reproducibly by this method, fine discrimination of antibody molecules differing by isoelectric points $<0.4 \mathrm{pH}$ units cannot be accomplished. Nevertheless, this level of discrimination does permit comparisons among antibodies of different specificities.

The anti-DNA antibodies found in cryoglobulins were more restricted than those present in whole serum. The alkaline bands were absent, suggesting that antibodies with isoelectric points of slightly acidic or neutral $\mathrm{pH}$ are more cryoprecipitable.
Although anti-DNA antibodies appear somewhat restricted, they are more heterogeneous than initially reported (20). This difference is likely due to the study of affinity purified anti-DNA antibody in the earlier report. Those antibodies were isolated by immunoglobulin class and by antigenic specificity, probably resulting in some antibody loss and selection for high affinity antibody. The sucrose method has the distinct advantage of eliminating this selection process.

In the limited number of SLE patients studied, there were no obvious spectrotypes that could be associated with the presence or absence of diffuse glomerulonephritis. The restricted antinative-DNA antibody spectrotypes might merely reflect the absence of antibody already bound as immune complexes or deposited in tissue. The similar spectrotypes for antidenatured DNA antibodies into the major regions $\mathrm{pH} \mathrm{5-7}$ and $\mathrm{pH}$ 8.5-10 and the relative absence of bands $\mathrm{pH}$ 7-8.5 seen in spontaneous human SLE, drug-induced lupus, and in immune rabbit serum suggests activation of similar B cell clones. Polyclonal B cell activation by LPS induced antipoly A antibodies that were quite similar to spontaneous antibody, suggesting that similar B cell clones produce this autoantibody in normal and autoimmune mice. Thus, the cells producing antinucleic acid antibodies may be similar whether they are activated spontaneously, after immunization, or as a consequence of polyclonal stimulation.

Spontaneous antinative DNA antibodies were more heterogeneous in mice than in humans. Rheumatoid factors reactive with anti-DNA antibodies have been reported in MRL/lpr mice (21) and could account for some of the increased heterogeneity.

Heterogeneous anti-DNA antibodies have been reported in autoimmune mice $(22,23)$. Antibodies from renal elutes were more restricted than serum antibodies. There was an increase in alkaline bands in serum as disease manifestations appeared (22). We likewise observed alkaline bands in serum, although there was no clear correlation between alkaline bands and disease features or severity.

These studies suggest unique antibody spectrotypes with varying degrees of restriction for different nucleic acid antigens. Furthermore, spontaneous and induced autoantibodies have a similar restriction in B lymphocyte clones producing autoantibodies.

\section{ACKNOWLEDGMENTS}

This work was supported by the Veterans Administration, the National Institutes of Health grant AM-25310, and the Rosalind Russell Arthritis Center AM-20684.

The authors wish to thank Dr. A. Bakshi and Dr. S. Koboyashi for establishment and maintenance of the hybridoma line, and Mrs. Sally Walsh for excellent editorial assistance. 


\section{REFERENCES}

1. Talal, N., and A. D. Steinberg. 1974. The pathogenesis of autoimmunity in New Zealand Black Mice. Curr. Top. Microbiol. Immunol. 64: 79-103.

2. Koffler, D., R. Carr, V. Agnello, R. Thoburn, and H. G. Kunkel. 1971. Antibodies to polynucleotide in human sera: antigenic specificity and relation to disease. J. Exp. Med. 134: 294-312.

3. Koffler, D., P. H. Schur, and H. G. Kunkel. 1967. Immunologic studies concerning the nephritis of systemic lupus erythematosus. J. Exp. Med. 126: 607-624.

4. Burnet, F. M. 1959. The clonal selection of acquired immunity. University Press, Cambridge, England.

5. Press, J. L., and N. R. Klinman. 1973. Isoelectric analysis of neonatal monofocal antibody. Immunochemistry. 10: 621-627.

6. Cohen, A. S., W. E. Reynolds, E. C. Franklin, J. P. Kulka, M. W. Ropes, L. E. Shulman, and S. L. Wallace. 1971. Preliminary criteria for the classification of systemic lupus erythematosus. Bull. Rheum. Dis. 21 : 643.

7. Plescia, O. J., W. Braun, and V. C. Palczuk. 1964. Production of antibodies to denatured deoxyribonucleic acid (DNA). Proc. Natl. Acad. Sci. U. S. A. 52: 279-284.

8. Fischbach, M., J. R. Roubinian, and N. Talal. 1978. Lipopolysaccharide induction of IgM antibodies to polyadenylic acid in normal mice. J. Immunol. 120: 18561861 .

9. Tung, A. R., and A. Nisonoff. 1975. Isolation of individual A/J mice of anti-p azophenylarsonate antibodies bearing cross-reactive idiotype. J. Exp. Med. 141: 112-126.

10. Talal, N., and R. C. Gallo. 1972. Antibodies to DNA/RNA hybrid in systemic lupus erythematosus. Nature (Lond.). 240: 240-242.

11. Locker, J. D., M. E. Medof, R. M. Bennett, and S. Sukhunyaraksa. 1977. Characterization of DNA used to assay sera for anti-DNA antibodies: determination of the specificities of anti-DNA antibodies in SLE and nonSLE rheumatic disease states. J. Immunol. 118: 694-701.

12. Attios, M. R., R. A. Sylvester, and N. Talal. 1973. Filter radioimmunoassay for antibodies to reovirus RNA in systemic lupus erythematosus. Arthritis Rheum. 16: 719-721.

13. March, S. C., I. Parikh, and P. Cuatrecasus. 1974. A simplified method for cyanogen bromide activation of agarose for affinity chromatography. Anal. Biochem. 60: $149-152$.

14. Glass, D., and P. Shur. 1977. Autoimmunity and systemic lupus erythematosus. In Autoimmunity. N. Talal, editor. Academic Press, Inc., New York. 18: 545-568.

15. Koffler, D., V. Agnello, R. Winchester, and H. G. Kunkel. 1973. The occurrence of single-stranded DNA in the serum of patients with systemic lupus erythematosus and other diseases. J. Clin. Invest. 52: 198-204.

16. Laurenzi, M. A., and H. Link. 1978. Localization of the immunoglobulins $G, A$, and $M$, beta-trace protein and gamma-trace protein on isoelectric focusing of serum and cerebrospinal fluid by immunofixation. Acta Neurol. Scand. 58: 141-148.

17. Hosein, Z. Z., and K. P. Johnson. 1981. Isoelectric focusing of cerebrospinal fluid proteins in the diagnosis of multiple sclerosis. Neurology. 31: 70-76.

18. Osserman, C. F., and K. Takatsuki. 1963. Role of an abnormal, myeloma-type gamma globulin in the pathogenesis of the skin lesions of papular mucinosis. J. Clin. Invest. 42: 962. (Abstr.).

19. James, K., H. Fudenberg, W. L. Epstein, and J. Shuster. 1967. Studies on a unique diagnostic serum globulin in papular mucinosis. Clin. Exp. Immunol. 2: 153-166.

20. Fischbach, M., and N. Talal. 1979. Electrophoretic restriction of antibodies to native DNA isolated from SLE serum by affinity chromatography. Clin. Res. 47A. (Abstr.).

21. Izui, S., and R. A. Givenberg. 1980. Circulating antiDNA-rheumatoid factor complexes in MRL/l mice. Clin. Immunol. Immunopathol. 15: 535-551.

22. Ebling, F., and B. H. Hahn. 1980. Restricted subpopulations of DNA antibodies in kidneys of mice with systemic lupus. Arthritis Rheum. 23: 392-403.

23. Dang, H., and R. Harbeck. 1979. A comparison of antiDNA antibodies from serum and kidney eluates of NZB $\times$ NZW F $F_{1}$ mice. Arthritis Rheum. 22: 603. (Abstr.). 